\title{
Myriapods (Arthropoda, Myriapoda) in the Pantanal of Poconé, Mato Grosso, Brazil
}

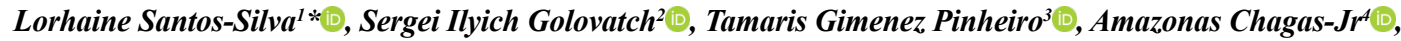 \\ Marinêz Isaac Marques ${ }^{4}$ \& Leandro Dênis Battirola ${ }^{1}$ ([D \\ ${ }^{1}$ Universidade Federal de Mato Grosso, Instituto de Ciências Naturais, Humanas e Sociais, Programa de \\ Pós-Graduação em Ciências Ambientais, Av. Alexandre Ferronato, 1.200, Setor Industrial, 78557-267, \\ Sinop, MT, Brasil \\ ${ }^{2}$ Institute for Problems of Ecology and Evolution, Russian Academy of Sciences, Moscow, Russia \\ ${ }^{3}$ Universidade Federal do Piaui, Avenida Cícero Eduardo, S/N, Junco, 64607-675, Picos, PI, Brasil \\ ${ }^{4}$ Universidade Federal de Mato Grosso, Instituto de Biociencias, Departamento de Biologia e Zoologia, \\ Avenida Fernando Corrêa da Costa, 2.367, Boa Esperança, 78060-900, Cuiabá, MT, Brasil \\ *Corresponding author: Lorhaine Santos-Silva, e-mail: lorhaine.silva@gmail.com
}

SANTOS-SILVA, L., GOLOVATCH, S. I., PINHEIRO, T. G., CHAGAS-JR, A., MARQUES, M. I., BATTIROLA, L. D. Myriapods (Arthropoda, Myriapoda) in the Pantanal of Poconé, Mato Grosso, Brazil. Biota Neotropica 19(3): e20180631. http://dx.doi.org/10.1590/1676-0611-BN-2018-0631

\begin{abstract}
The Brazilian Pantanal biome is one of the largest and most important floodplains in the world by virtue of its biodiversity and indispensable ecological services on local, regional, and global scales. Despite this importance, many gaps remain concerning its biodiversity as well as its generation and maintenance mechanisms. In view of expanding the information about its biological diversity, we compiled a list of Myriapoda (Arthropoda) species occurring in the Pantanal of Poconé, Mato Grosso, Brazil, based on the records from literature and on the specimens available in the zoological collections of Federal University of Mato Grosso -UFMT. A total of 33 Myriapoda species were recorded in the region. The Diplopoda species (20 spp.; 60.6\%) are distributed 'between four orders: Polydesmida, represented by five families (Chelodesmidae, notably, with three species; Paradoxosomatidae and Pyrgodesmidae, with two species each; and Cyrtodesmidae and Fuhrmannodesmidae, with one species each, recently recorded in the region); Spirostreptida, represented by Spirostreptidae, with eight species; Spirobolida, with two species (one Rhinocricidae and one not identified); and Polyxenida. The Chilopoda (10 spp.; 30.3\%) belong to three orders: Scolopendromorpha, with four species of the family Scolopendridae, two Scolopocryptopidae species, and one Cryptopidae species; Geophilomorpha, with the families Aphilodontidae and Schendylidae, with one species each; and Lithobiomorpha, with one Henicopidae species. Symphyla was represented by only two species $(6.1 \%)$ of the family Scutigerellidae; and Pauropoda (3.0\%) by a single species of Pauropodidae. The Myriapoda species richness, as well as the high number of new records in recent studies reinforce the importance of the northern region of the Pantanal biome as a diversity center with potential priority for measures aimed at the conservation of its many habitats.
\end{abstract}

Keywords: Biodiversity, Chilopoda, Diplopoda, Pauropoda, Symphyla.

\section{Miriápodes (Arthropoda, Myriapoda) do Pantanal de Poconé, Mato Grosso, Brasil}

Resumo: O Pantanal de Mato Grosso é uma das maiores e mais importantes planícies de inundação do mundo, em relação à sua biodiversidade e aos seus indispensáveis serviços ecológicos em escalas locais, regionais e globais. Apesar dessa importância, existem, ainda, muitas lacunas sobre o conhecimento de sua biodiversidade, bem como de seus mecanismos geradores e mantenedores. Desse modo, a fim de contribuir com o conhecimento de sua diversidade biológica compilamos, com base na literatura e em espécimes disponíveis nas coleções e acervos zoológicos da Universidade Federal de Mato Grosso-UFMT, uma lista de espécies de miriápodes (Arthropoda, Myriapoda) ocorrentes no Pantanal de Poconé, Mato Grosso, Brasil. Um total de 33 espécies de Myriapoda foi registrado como ocorrentes nessa região. As espécies de Diplopoda (20 spp.; 60,6\%), estão distribuídas em quatro ordens. Polydesmida está representada por cinco famílias, com destaque para Chelodesmidae com três espécies, Paradoxosomatidae e Pyrgodesmidae, com duas espécies cada, além de Cyrtodesmidae e Fuhrmannodesmidae, com uma espécie cada, recentemente registradas para essa região; Spirostrepida representada por Spirostreptidae, 
com oito espécies; Spirobolida, com duas espécies (uma Rhinocricidae e uma não identificada); e Polyxenida. Os Chilopoda (10 spp.; 30,3\%) estão distribuídos em três ordens: Scolopendromorpha, com quatro espécies da família Scolopendridae, duas espécies de Scolopocryptopidae e uma espécie de Cryptopidae; Geophilomorpha, com as famílias Aphilodontidae e Schendylidae, com uma espécie cada; e Lithobiomorpha, com uma única espécie de Henicopidae. Symphyla foi representada por apenas duas espécies $(6,1 \%)$ da família Scutigerellidae e Pauropoda (3,0\%) por uma única espécie de Pauropodidae. A riqueza de espécies de Myriapoda, bem como a alta proporção de novos registros em estudos recentes, reforçam a importância da região norte do Pantanal como um centro de diversidade com potencial prioridade às medidas de conservação de seus variados habitats.

Palavras-chave: Biodiversidade, Chilopoda, Diplopoda, Pauropoda, Symphyla.

\section{Introduction}

Wetlands are defined as ecosystems inserted at the interface between terrestrial and aquatic, continental and coastal, natural or artificial environments which may permanently or periodically be flooded by shallow, fresh, briny, or salt water (Junk et al. 2015). These areas provide important ecological services on both local and global scales, with functional values related mainly to the renewal of groundwater stores, storage and maintenance of increased atmospheric humidity, protection against soil erosion, water purification, organic carbon storage, and their consequent impact on climatic conditions (Denny 1994). They also feature a mosaic of seasonally flooded habitats that are home to numerous species of significant value to biodiversity (Junk et al. 2006, Nunes-da-Cunha \& Junk 2015).

Brazil is a country with a vast territory that includes a large variety of wetland types and their consequent broad biodiversity (Junk et al. 2015). The 'Pantanal' biome is one of the largest wetlands in the world, encompassing an area of approximately $138,000 \mathrm{~km}^{2}$ (Da Silva \& Abdon 1998, Fantin-Cruz et al. 2010). The Pantanal is subject to a predictable monomodal flood pulse, with marked aquatic and terrestrial phases that alternate annually (Nunes-da-Cunha \& Junk 2015). This floodplain has four well-defined seasonal periods: dry season, rising water, high water, and receding water (Heckman 1998). The region floods due to the lateral overflow of great rivers or lakes, precipitation, or underground water, and the flood is classified according to its amplitude, frequency, predictability and strength (Signor et al. 2010, Junk et al. 2015).

Based on the heterogeneity of landscapes and on the intensity and duration of floods, Adámoli (1982) categorized the Pantanal into 11 sub-regions. The northern Pantanal region belonging to Mato Grosso State is formed by the sub-regions of Poconé, Cáceres, and Barão de Melgaço. The Pantanal of Poconé sub-region accounts for $11 \%$ of the entire Pantanal, covering 11,945 km² (Signor et al. 2010). This region has a wide variety of vegetation formations such as 'murundu' fields, clean fields, mixed formations of evergreen flooded forests ('landizal') with dominance of Calophyllum brasiliensis Cambess (Clusiaceae) and 'cerradão', dense tree savannas (mountain ranges), in addition to monodominant dense fields of Callisthene fasciculata (Spr.) Mart. (Vochysiaceae) ('carvoal'), Attalea phalerata Mart. (Arecaceae) ('acurizal'), Vochysia divergens Pohl. (Vochysiaceae) ('cambarazal'), as well as aquatic and semi-aquatic vegetations (Silva et al. 2000, Santos et al. 2003, Arieira \& Nunes-da-Cunha 2006, Nunes-da-Cunha et al. 2007, 2010, Nunes-da-Cunha \& Junk 2015).
Although the Pantanal of Mato Grosso state is known for its importance as a wetland, many gaps exist knowledge about regarding its biodiversity and maintenance mechanisms, especially well-defined species-richness values for some groups or lists of species. This clearly demonstrates the need for more in-depth knowledge of the biology and taxonomy of the species occurring in that region (Junk et al. 2006), especially for poorly studied taxa with sparse information like Myriapoda (e.g. Golovatch et al. 2005, Junk et al. 2006, Battirola et al. 2009, 2017, Pinheiro et al. 2009, 2011, Santos-Silva et al. 2018a,b).

Myriapoda are widespread across all continents, except Antarctica, with greatest diversity concentrated in the tropical and hot temperate regions. They are widely distributed in several habitats such as soil, plant litter, tree barks and trunks, forest canopy, fields and pastures, dense forests, deserts, caverns, and coastal areas (Hopkin \& Read 1992, Golovatch et al. 1995, 2005, Knysak \& Martins 1999, Kime \& Golovatch 2000, Scheller 2002, Scheller \& Adis 2002, Edgecombe \& Giribet 2007, Minelli \& Golovatch 2013, Battirola et al. 2017). At present, this group consists of four taxonomic classes: Diplopoda, Chilopoda, Symphyla, and Pauropoda.

The Diplopoda correspond to a great part of the soil and plantlitter macrofauna in most terrestrial biomes, where they act on the decomposition, reduction, and fragmentation of plant litter (Hopkin \& Read 1992, Golovatch et al. 1995, Hoffman et al. 2002, Battirola et al. 2011), in addition to constituting the largest group of Myriapoda, with more than 12,000 species (Sierwald \& Bond 2007). The Chilopoda are important predators that control populations of other arthropods and small vertebrates. They currently comprise five orders, with approximately 3,300 species described around the world (Edgecombe $\&$ Giribet 2007). The lowest diversity taxa of myriapods comprise the Symphyla and the Pauropoda. The former corresponds to the group of Myriapoda with the lowest species richness, containing around 200 species distributed into two families and 15 genera (Scheller \& Adis 2002). The Pauropoda, in turn, have 0.5 to $1.5 \mathrm{~mm}$ in length, with a world fauna consisting of two orders, five families, 30 genera, and around 708 species described (Scheller 2002).

These organisms are of utmost importance for the balance of systemic functions, since they act as predators and decomposers, but little research has been undertaken in the Pantanal of Mato Grosso State on the biology, taxonomy, and diversity of Myriapoda. The present study presents a compilation of information available in the literature and in different zoological collections of the Federal University of Mato Grosso on the occurrence of these taxa in the Pantanal of Pocone - MT, to expand the knowledge of the biodiversity of the Pantanal of Mato Grosso State. 


\section{Material and Methods}

For the data compilation, we used Myriapoda (Diplopoda, Chilopoda, Symphyla, and Pauropoda) occurrence metadata available in the scientific literature referring to the Pantanal of Poconé region (Figure 1) as well as the results obtained in studies led by the teams of the Laboratory of Ecology and Taxonomy of Terrestrial and Aquatic Arthropods (LETA) of the Bioscience Institute at the Federal University of Mato Grosso, in Cuiabá, Mato Grosso; of the Biological Collection of Southern Amazon (ABAM) at the Federal University of Mato Grosso, in Sinop, Mato Grosso; and of the Zoological Collection of the Federal University of Mato Grosso, in Cuiabá, Mato Grosso.

In addition to the species survey, information is provided about their record location, associated vegetation types, site of deposition of the control material sampled in the region and collection method. Different sampling methodologies were used in the studies with myriapods, e.g., Winkler and mini-Winkler extractors, ground and tree photo-eclectors, pitfall traps, manual collection, and canopy fogging (Table 1). Species determined only at generic level and present in more than one habitat or record were grouped as a single taxon, in view of the difficulty in determining these individuals sampled in different studies. The Polyxenida, which were not identified at lower taxonomic levels in any of the studies for this region, were considered a single taxon.

\section{Results}

Thirty-three Myriapoda taxa were recorded in the Pantanal of Poconé, corresponding to species of Diplopoda (20 spp.; 60.6\%), followed by Chilopoda (10 spp.; 30.3\%), Symphyla (2 spp.; 6.1\%), and Pauropoda (1 sp.; 3.0\%) (Table 1).

The 20 diplopod species were distributed into four orders, the largest being Polydesmida (9 spp.; 45\%) and Spirostreptida (8 spp.; 40\%), followed by Spirobolida (2 spp.; 10\%) and Polyxenida (1 sp.; 5\%).

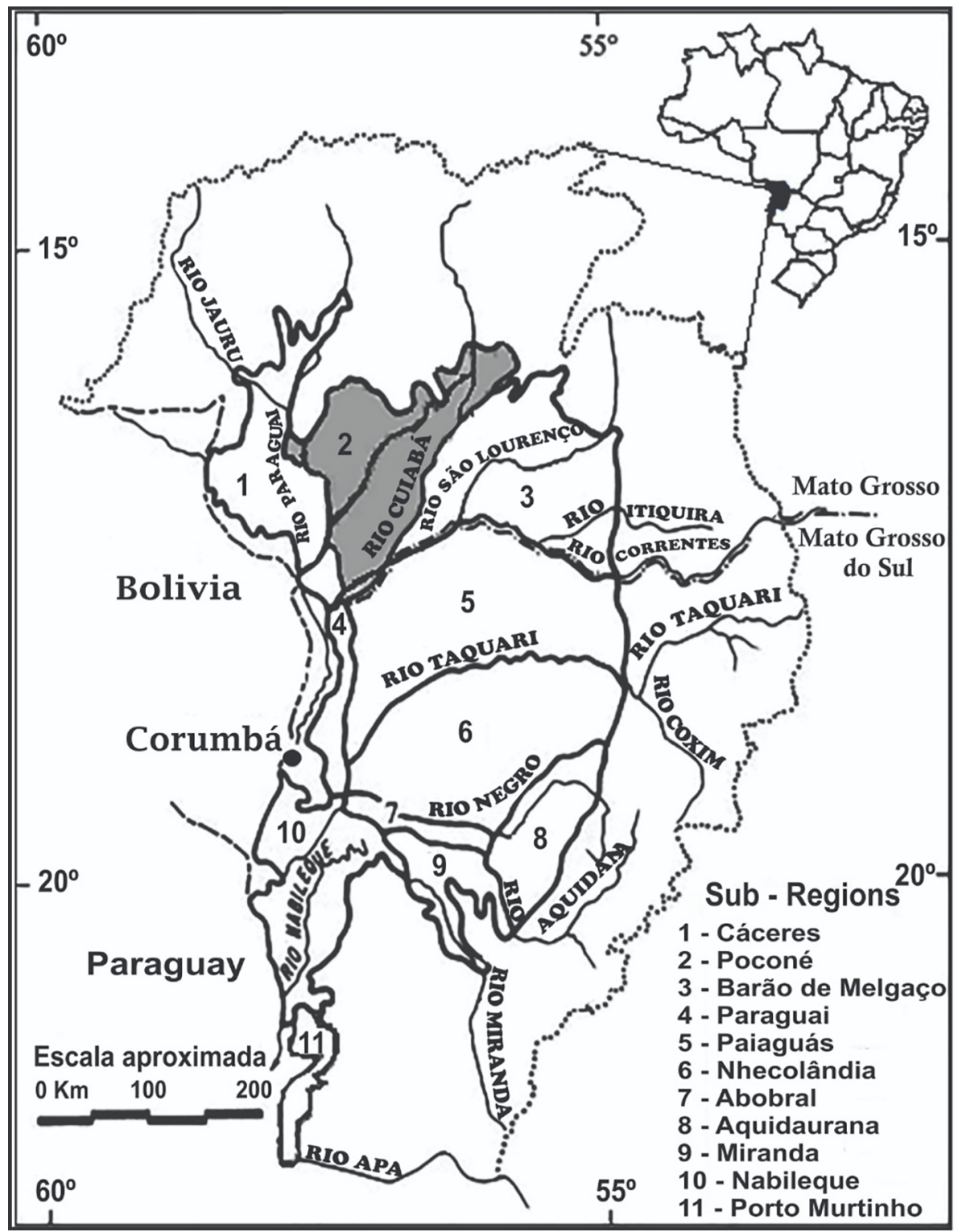

Figure 1. Map of the Pantanal and its sub-regions, between the parallels $16^{\circ}$ and $21^{\circ} \mathrm{S}$ and the meridians $55^{\circ}$ and $58^{\circ} \mathrm{W}$, highlighting the Pantanal of Poconé (Modified from Silva et al., 2000). 


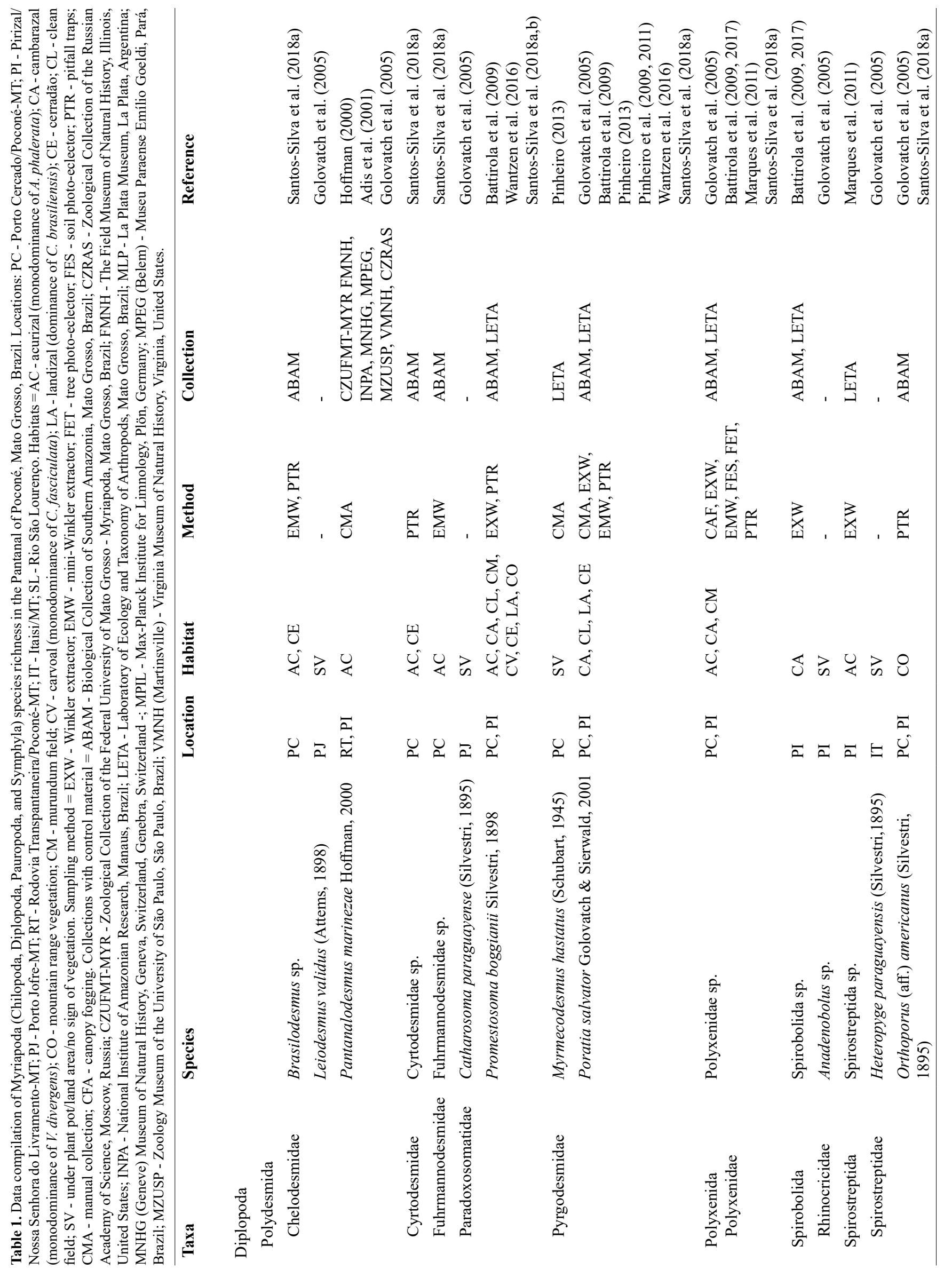




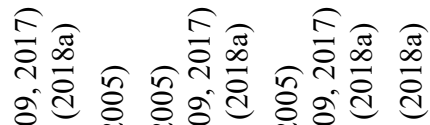

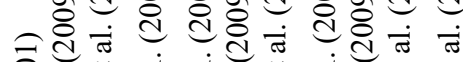

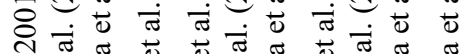

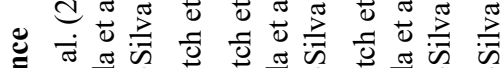

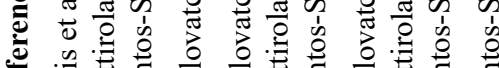

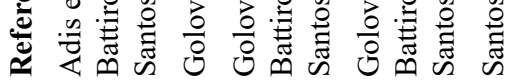

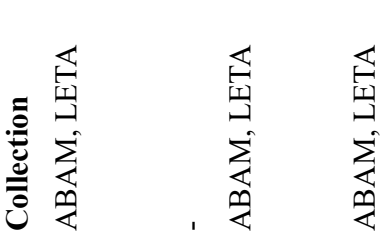

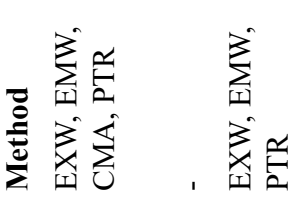

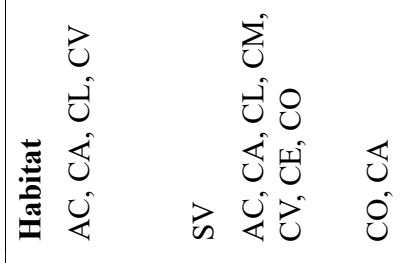

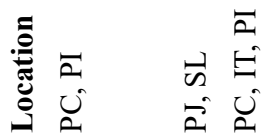

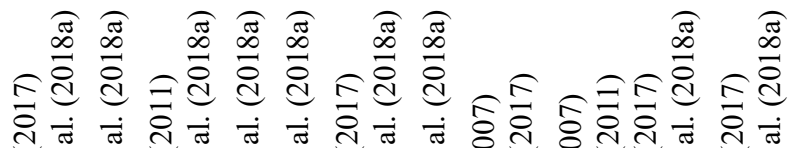

त 0 ब

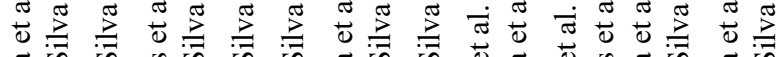

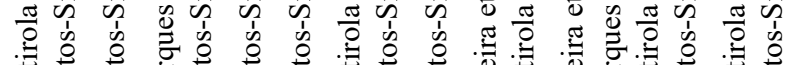

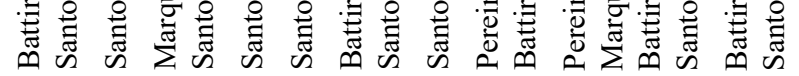

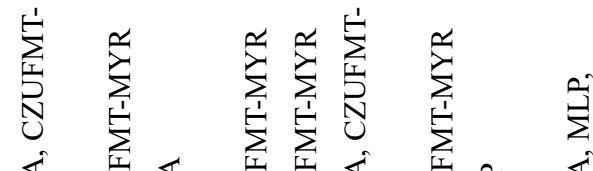

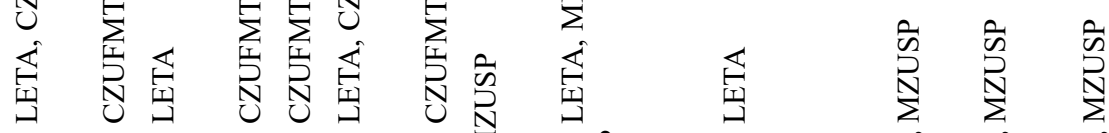

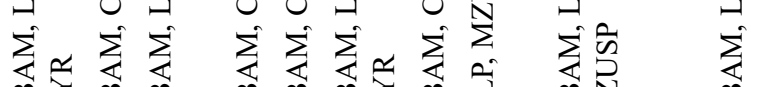

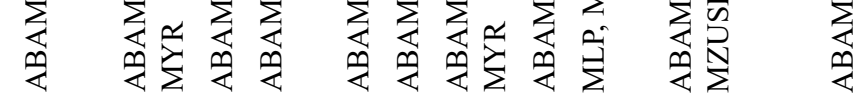

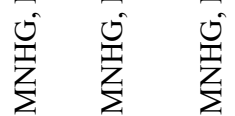

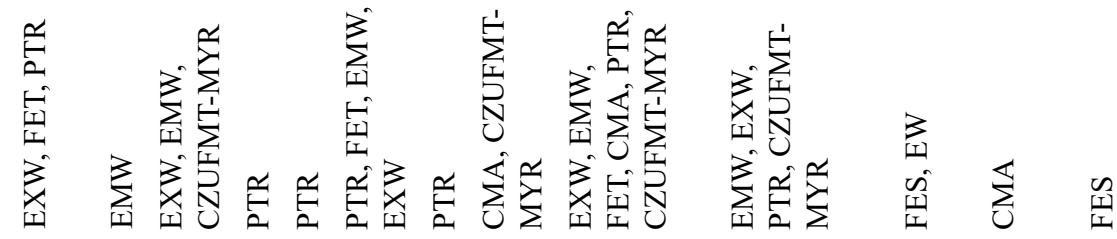

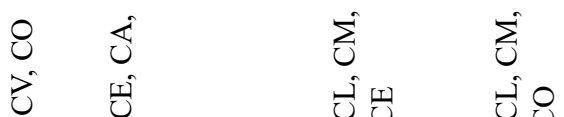

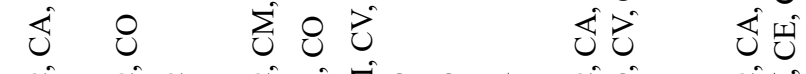

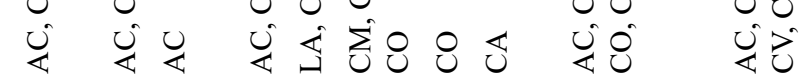

$\bar{a} \quad \bar{a} \quad \vec{a} \quad \bar{a}$

¿

요

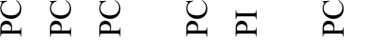

$\vec{i}$

उ के उ
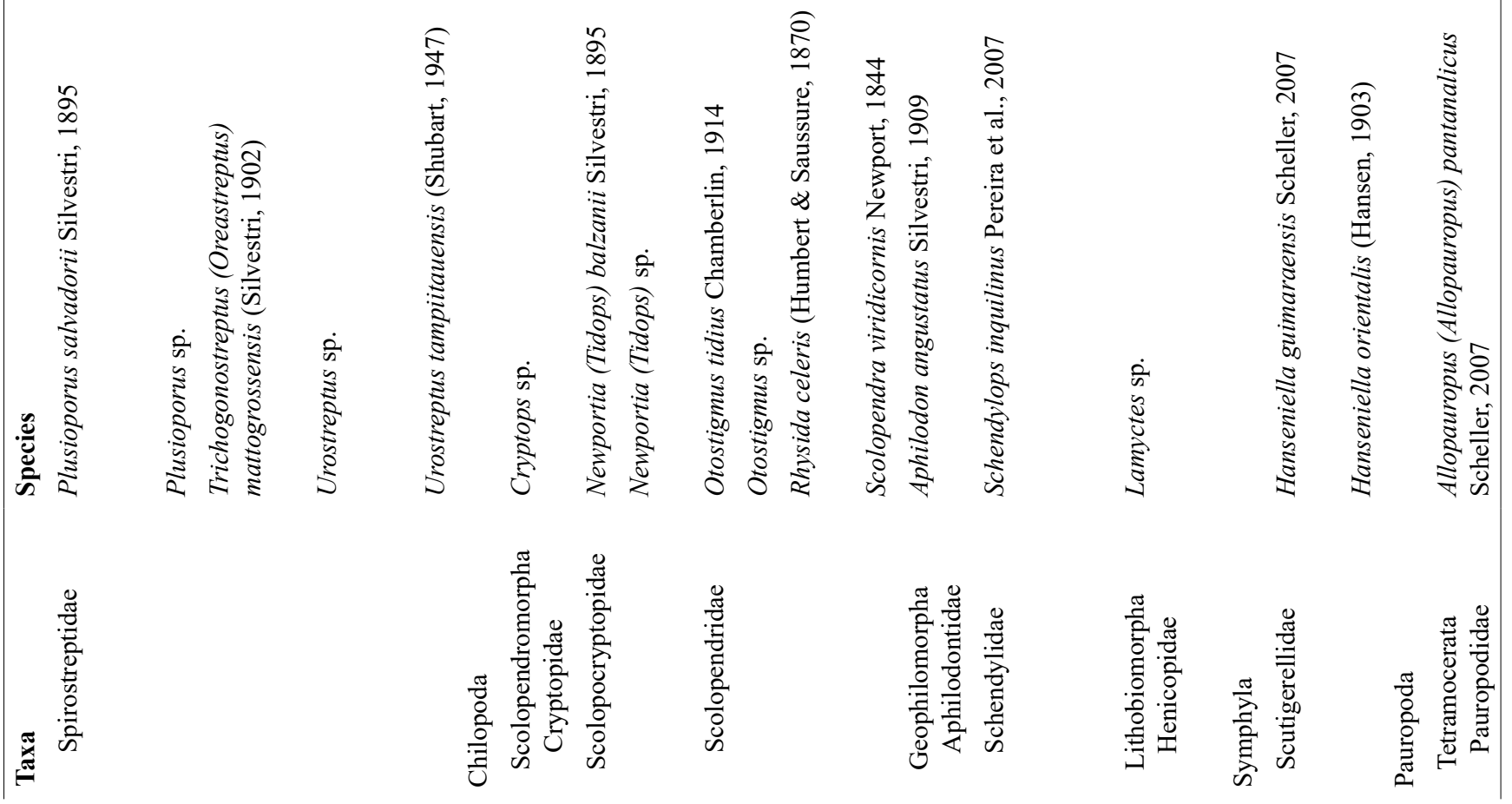
Polydesmida corresponded to five families: Chelodesmidae, which stood out with three records (Brasilodesmus sp., Leiodesmus validus (Attems, 1898), and Pantanalodesmus marinezae Hoffman, 2000); Paradoxosomatidae, with two species (Catharosoma paraguayense (Silvestri, 1895) and Promestosoma boggianii Silvestri, 1898; Pyrgodesmidae, with Myrmecodesmus hastatus (Schubart, 1945) and Poratia salvator Golovatch \& Sierwald, 2001; and Cyrtodesmidae and Fuhrmannodesmidae, with one morphospecies each (Table 1). In Spirostreptida, Spirostreptidae species predominated, notably Heteropyge paraguayensis (Silvestri, 1895), Orthoporus (aff.) americanus (Silvestri, 1895), Plusioporus salvadorii Silvestri, 1895, Plusioporus sp., Trichogonostreptus (Oreastreptus) mattogrossensis (Silvestri, 1902), Urostreptus tampiitauensis (Shubart, 1947), and Urostreptus sp. The Spirobolida were represented by two species, only: Anadenobolus sp. (Rhinocricidae) and Spirobolida sp. (indeterminated family) (Table 1). Lastly, Polyxenida was represented by the family Polyxenidae (Table 1).

The Chilopoda were represented by species of three orders: Scolopendromorpha (7 spp.; 70\%), Geophilomorpha (2 spp.; 20\%), and Lithobiomorpha (1 sp.; 10\%). Noteworthy families among the Scolopendromorpha were the Scolopendridae, represented by Otostigmus tidius Chamberlin, 1914, Otostigmus sp., Rhysida celeris (Humbert \& Saussure, 1870), and Scolopendra viridicornis Newport, 1844. There were also the families Cryptopidae, represented by Cryptops sp., and Scolopocryptopidae, represented by Newportia (Tidops) balzanii Silvestri, 1895 and Newportia (Tidops) sp. Among the Geophilomorpha, two families were recognized: Aphilodontidae, with the species Aphilodon angustatus Silvestri, 1909, and Schendylidae, with Schendylops inquilinus Pereira et al., 2007 (Table 1). For Lithobiomorpha, only Henicopidae were recorded, represented by Lamyctes sp. Symphyla was found in only two Scutigerellidae species: Hanseniella guimaraensis Scheller, 2007 and Hanseniella orientalis (Hansen, 1903), while Pauropoda was represented by only one Pauropodidae species: Allopauropus (Allopauropus) pantanalicus Scheller, 2007.

As for the different types of methodologies and habitats in which the studies were carried out, the highest species occurrence was recorded for the 'acurizal' (15 spp.; 18.5\%), 'cambarazal' (14 spp.; 17.3\%), and mountain range (14 spp.; 17.3\%) areas, whereas the lowest were obtained in 'cerradão' (8 spp.; 9.9\%), 'murundum' field (7 spp.; 8.6\%), 'carvoal' (7 spp.; 8.6\%), clean field (6 spp.; 7.4\%), and 'landizal' (3 spp.; $3.7 \%$ ) areas. Seven species $(8.6 \%)$ cited in the literature as occurring in the Pantanal of Poconé sub-region do not have an indication of the type of habit in which they were sampled (Table 1).

\section{Discussion}

In the Pantanal of Poconé, the Myriapoda fauna has considerable species richness; however, to the present date, it has been characterized by the dominance of few taxa (Golovatch et al. 2005, Battirola et al. 2009, Pinheiro et al. 2009, 2011, Santos-Silva et al. 2018a). The majority of species corresponds to large-sized individuals, which are thus more easily collected, corroborating Golovatch et al. (2005). The same was described in recent studies on Chilopoda (Battirola et al. 2017, Santos-Silva et al. 2018a). These results can explain why the Symphyla and Pauropoda showed a lower number of species in studies conducted in that region: probably because these myriapods are small-sized, have little mobility, and are associated with the soil organic layers, their sampling is more difficult. This is especially true considering the sampling methods already used for arthropods in the region such as pitfall traps and Winkler extractors (e.g. Battirola et al. 2017, Scheller 2007), which are considered unsuitable for the sampling of Symphyla and Pauropoda (Battirola et al. 2017). Those myriapods should preferably be sampled using specific extraction methods such as soil flotation, Kempson apparatuses, and Berlese funnels (Scheller 2002, Scheller \& Adis 2002).

Other surveys have shown structural differences regarding assemblages of Myriapoda in comparison with that sampled from the Pantanal of Poconé sub-region in Mato Grosso State. In Central Amazon, assemblages are mostly constituted by small-sized taxa such as Henicopidae (Chilopoda), Pyrgodesmidae, Furhmannodesmidae (Diplopoda), Pauropodinae (Pauropoda) and Scutigerellidae (Symphyla), though with elevated species richness (Adis 1997, Adis \& Harvey 2000, Adis et al. 2002, Foddai et al. 2002, Hoffman et al. 2002, Scheller \& Adis 2002, Scheller 2002). For the Pantanal of Poconé, Spirostreptidae, Paradoxosomatidae, and Chelodesmidae predominate among the Diplopoda, while the Scolopendridae prevail among the Chilopoda, characterizing the assemblage as containing large-sized individuals and a smaller number of species in each habitat (e.g. Golovatch et al. 2005, Scheller 2007, Battirola et al. 2017, SantosSilva et al. 2018a). An example of such variation can be verified in the Myriapod species richness of the Ducke Reserve near the city of Manaus, Central Amazon, whose 73 species occurring in the area are divided into 31 Pauropoda, 23 Chilopoda, 14 Diplopoda, and five Symphyla (Adis et al. 2002).

Despite the remarkable difference in Myriapoda assemblage structure in Central Amazon and Pantanal of Poconé, we must stress that studies conducted in the Pantanal and its sub-regions are still very recent (Adis et al. 2001, Golovatch et al. 2005, Pereira et al. 2007, Scheller 2007, Pinheiro et al. 2009, 2011, Battirola et al. 2009, 2017, Wantzen et al. 2016, Santos-Silva et al. 2018a,b) when compared with those performed in Central Amazon (Hoffman 1984, Adis 1986, 1992, 1997 , Tapia-Coral 1999, Adis \& Harvey 2000, Adis et al. 2002, Foddai et al. 2002, Hoffman et al. 2002, Scheller 2002, Scheller \& Adis 2002). Two other important factors are the difference in mechanisms responsible for maintaining the seasonality present in the Pantanal and in Central Amazon (e.g. Junk et al. 2015) and the distinct habitat structures of those areas. The Pantanal has sudden humidity drops throughout the year and vegetation types with prevalence of herbaceous plants on sandy soils and a consequently low nutritional content to support a diversified myriapod fauna (Golovatch et al. 2005).

The same variation is observed for Southern Amazon, which has also had its biological diversity recently investigated (Battirola et al. 2011, 2016, Noronha et al. 2015, Batistella et al. 2015). The Myriapoda fauna in the Pantanal of Poconé and Southern Amazon can be considered similar in terms of assemblage structure, given the size of its individuals, species richness, and proportion of new records, besides the short period of studies and sampling carried out in the region. Battirola et al. (2016) reported the occurrence of 20 Myriapoda species distributed into Chilopoda (7 spp.) and Diplopoda (13 spp.) in the State Park of Cristalino, Mato Grosso state. Another survey conducted in Southern Amazon, in the municipality of Cotriguaçu, Mato Grosso state, also 
had 20 diplopod species recorded, consisting mostly of Polydesmida (9 spp.), Spirostreptida (5 spp.), Spirobolida (5 spp.) and Polyxenida (1 sp.) (Battirola et al. 2011). Batistella et al. (2015) analyzed the distribution of three Spirostreptidae species in an Amazon area of Mato Grosso State and associated the occurrence of these species with the abiotic conditions of the habitats, evidencing the larger size of species in that region.

In the Pantanal, seasonal floods exert a limiting function on the vegetation, selecting species adapted to periodical conditions (Rebellato $\&$ Nunes-da-Cunha 2005, Arieira \& Nunes-da-Cunha 2006, Machado et al. 2012) and influencing the distribution of different vegetation types in the region (Nunes-da-Cunha \& Junk 2015); hence the movement of the fauna across habitats, including the Myriapoda (Battirola et al. 2009, 2017, Wantzen et al. 2016, Santos-Silva et al. 2018a,b). To tolerate the changes that take place in the habitat structure due to water seasonality, some myriapod species developed strategies to adapt to and survive in the Pantanal. The Polyxenida in this region showed a pattern of distribution between soil and tree canopies influenced by the seasonal variation of environmental conditions (Battirola et al. 2009). Poratia salvator and Promestosoma boggianii adapted their life cycle, reproduction, and phenology to the flood cycles occurring in the region (Pinheiro et al. 2009, 2011, Wantzen et al. 2016, Santos-Silva et al. 2018b), while other species developed temporary migratory strategies (Adis et al. 2001, Battirola et al. 2009, 2017).

The Myriapoda have a fundamental role in the balance of ecosystems, as they act by fragmenting organic matter - the feed base of other animals (e.g. Diplopoda, Symphyla, Pauropoda) - in addition to being important predators that help to control the population of other organisms (e.g. Chilopoda) (Hoffman et al. 2002, Edgecombe \& Giribet 2007, Battirola et al. 2011, Minelli \& Golovatch 2013, Noronha et al. 2015, Guizze et al. 2016). The great species richness of myriapod species, ocurrence of new records, and estimated number of species in the Pantanal (e.g. Golovatch et al. 2005, Battirola et al. 2009, Pinheiro et al. 2009, 2011, Santos-Silva et al. 2018a) reinforce the importance of the region as an area of wide diversity, with potential priority for conservation measures. It is thus paramount to acknowledge the diversity of macrohabitats in that region for the maintenance of this diversity; and to protect the structural and functional integrity of these important wetlands.

\section{Acknowledgements}

We thank the Pantanal Research Center (Centro de Pesquisas do Pantanal - CPP), the National Institute of Science and Technology in Wetlands (Instituto Nacional de Ciência e Tecnologia em Áreas Úmidas - INAU/UFMT/CNPq), the Mato Grosso Foundation for Research Support (Fundação de Amparo à Pesquisa do Estado de Mato Grosso - FAPEMAT) (Process PRONEX/FAPEMAT/CNPq $838265 / 2009$ ) and the National Council for Scientific and Technological Development (Conselho Nacional de Desenvolvimento Científico e Tecnológico - CNPq) (Process 472215/2013-2) for their financial assistance and provision of logistics to this study. The Coordination of Improvement of Higher Education Personnel (Coordenação de Aperfeiçoamento de Pessoal de Nível Superior - CAPES) for the granting of a scholarship to LSS. The Federal University of Mato
Grosso, specifically, the Post-Graduate Program in Environmental Sciences (Universidade Federal de Mato Grosso - UFMT, Sinop).

\section{Author Contributions}

Leandro Dênis Battirola: Substantial contribution in the concept and design of the study; Contribution to manuscript preparation; Contribution to data interpretation.

Lorhaine Santos-Silva: Substantial contribution in the concept and design of the study; Contribution to manuscript preparation; Contribution to data interpretation.

Serguei Ilyich Golovatch: Contribution to critical revision, adding intellectual content.

Tamaris Gimenez Pinheiro: Contribution to critical revision, adding intellectual content.

Amazonas Chagas-Jr: Contribution to critical revision, adding intellectual content.

Marinêz Isaac Marques: Contribution to critical revision, adding intellectual content.

\section{Conflicts of Interest}

The authors declare that they have no conflict of interest related to the publication of this manuscript.

\section{Ethics}

All biological material collected in the different studies evaluated in this data compilation, has the appropriate collection permits in environmental bodies.

\section{Availability of Data and Material}

All material collected from Myriapoda (Diplopoda,Chilopoda, Symphyla and Pauropoda) is duly registered and deposited in the Acervo Biológico da Amazônia Meridional - ABAM, in the zoological collections of UFMT, and others zoological collections.

\section{References}

ADÁMOLI, J. A. 1982. O Pantanal e suas relações fitogeográficas com os Cerrados. Discussão sobre o conceito de "Complexo do Pantanal". In Anais do $32^{\circ}$ Congresso Nacional de Botânica. UFPI- Teresina, Piauí, p. 109-119.

ADIS, J. 1986. An "aquatic" millipede from a Central Amazonian inundation forest. Oecologia 68:347-349. https://link.springer.com/ article/10.1007\%2FBF01036737

ADIS, J. 1992. How to survive six months in a flooded soil: Strategies in Chilopoda and Symphyla from Central Amazonian floodplains. Stud. Neotrop. Fauna E. 27:(2-3), 117-129. http://dx.doi.org/10.1080/01650529209360872

ADIS, J. 1997. Estratégias de sobrevivência de invertebrados terrestres em florestas inundáveis da Amazônia Central: Uma resposta à inundação de longo período. Acta Amaz. 27:43-54. 1809-4392-aa-27-1-0043

ADIS, J. \& HARVEY, M.S. 2000. How many Arachnida and Myriapoda are there world-wide and in Amazonia. Stud. Neotrop. Fauna E. 35:139-141. http://hdl.handle.net/11858/00-001M-0000-000F-E060-1

ADIS, J., MARQUES, M.I. \& WANTZEN, K.M. 2001. First observations on the survival strategies of terriculous arthropods in the northern Pantanal wetland of Brazil. Andrias 15:127-128. 
ADIS, J., FODDAI, D., GOLOVATCH, S.I., HOFFMAN, R.L., MINELLI, A., DE MORAIS, J.W., PEREIRA, L.A., SCHELLER, U., SCHILEYKO, A.A \& MÜRMLI, M. 2002. Myriapoda at 'Reserva Ducke', Central Amazonia/ Brazil. Amazoniana 17(1-2):14-25.

ARIEIRA, J. \& NUNES-DA-CUNHA, C. 2006. Fitossociologia de uma floresta inundável monodominante de Vochysia divergens Pohl. (Vochysiaceae), no Pantanal Norte, MT, Brasil. Acta Bot. Bras. 20(3):569-580. 10.1590/ S0102-33062006000300007

BATTIROLA, L.D., MARQUES, M.I., ROSADO-NETO, G.H., PINHEIRO, T.G. \& PINHO, N.G.C. 2009. Vertical and time distribution of Diplopoda (Arthropoda, Myriapoda) in a monodominant forest in Pantanal of Mato Grosso, Brazil. Zoologia 26:479-487. 10.1590/S1984-46702009005000008

BATTIROLA, L.D., BRESCOVIT, A.D., PENA-BARBOSA, J.P.P., PINHEIRO, T.G. \& BATISTELLA, D.A. 2011. Diplopoda (Myriapoda, Arthropoda) da Fazenda São Nicolau, Cotriguaçu-MT. In Descobrindo a Biodiversidade da Fazenda São Nicolau (D.J. Rodrigues, T.J. Izzo \& L.D. Battirola, eds.). Pau e Prosa Comunicação Ltda, Cuiabá, p. 35-46.

BATTIROLA, L.D., SANTOS-SILVA, L., ALMEIDA, F.M., BATISTELLA, D.A., PENA-BARBOSA, J.P.P., CHAGAS-JUNIOR, A. \& BRESCOVIT, A.D. 2016. Artrópodes de solo do Parque Estadual do Cristalino, Mato Grosso. In Biodiversidade do Parque Estadual Cristalino (D.D.J. Rodrigues, J.D.C.D. Noronha, V.F. Vindica \& F.R. Barbosa, eds.). Áttema Editorial, Santo André-SP, p. 165-177.

BATTIROLA, L.D., GOLOVATCH, S.I., PINHEIRO, T.G., BATISTELLA, D.A., ROSADO-NETO, G.H., CHAGAS JR, A., BRESCOVIT, A.D. \& MARQUES, M.I. 2017. Myriapod (Arthropoda, Myriapoda) diversity and distribution in a floodplain forest of the Brazilian Pantanal. Stud. Neotrop. Fauna E. http://dx.doi.org/10.1080/01650521.2017.1397978

BATISTELLA, D.A., PINHEIRO, T.G., RODRIGUES, D.J. \& BATTIROLA, L.D. 2015. Distribuição de espécies de Spirostreptidae (Diplopoda Spirostreptida) em uma área na Amazônia mato-grossense. Acta Biol. Parana. 44(3-4):159-170. http://dx.doi.org/10.5380/abpr.v44i1-4.44121

DA SILVA, J.D.S.V. \& ABDON, M.D.M. 1998. Delimitação do Pantanal Brasileiro e Suas Sub-Regiões. Pesq. agropec. bras. 33:703- 711.https:// seer.sct.embrapa.br/index.php/pab/article/view/5050

DENNY, P. 1994. Biodiversity and wetlands. Wetl. Ecol. Manag. 3(1):55-61. https://link.springer.com/article/10.1007/BF00177296

EDGECOMBE, G.D. \& GIRIBET, G. 2007. Evolutionary biology of centipedes (Myriapoda: Chilopoda). Ann. Rev. Entomology 52:151-70. https://doi. org/10.1146/annurev.ento.52.110405.091326

FANTIN-CRUZ, I., GIRARD, P., ZEILHOFER, P., COLLISCHONN, W. \& CUNHA, C.N. 2010. Meso-scale phytophysiognomic units in the Northern Pantanal and their relations with geomorphology. Biota Neotropica 10(2): http://www.biotaneotropica.org.br/v10n2/en/ abstract?article+bn00410022010

FODDAI, D., SCHILEYKO, A.A. \& MINELLI, A. 2002. Lithobiomorpha. In Amazonian Arachnida and Myriapoda (J. Adis, ed.). Pensoft Publishers, Sofia, p. 475-478.

GOLOVATCH, S.I., HOFFMAN, R.L., ADIS, J. \& DE MORAIS, J.W. 1995. Identification plate for the millipede orders populating the Neotropical region south of Central Mexico (Myriapoda, Diplopoda). Stud. Neotrop. Fauna E. 30:159-164. 10.1080/01650529509360954

GOLOVATCH, S.I., HOFFMAN, R.L., ADIS, J., MARQUES, M.I., RAIZER, J., SILVA, F.H.O., RIBEIRO, R.A.K., SILVA, J.L. \& PINHEIRO, T.G. 2005. Milipedes (Diplopoda) of the Brazilian Pantanal. Amazoniana 18(34):273-288. 11858/00-001M-0000-000F-D961-B

GUIZZE, S.P.G., KNYSAK, I., BARBARO, K.C., KARAM-GEMAEL, M. \& CHAGAS-JR, A. 2016. Predatory behavior of three centipede species of the order Scolopendromorpha (Arthropoda: Myriapoda: Chilopoda). Zoologia 33(6): e20160026.10.1590/S1984-4689zool-20160026

HECKMAN, C.W. 1998. The Pantanal of Poconé. Biota and ecology in the northern section of the world's largest pristine wetland. Academic Publishers, Kluwer, Dordrecht.
HOFFMAN, R.L. 1984. A new species of Epinannolene from the Amazon Basin, Brazil (Spirostreptida: Pseudonannolenidae). Myriapodologica 13(1): 91-94.

HOFFMAN, R.L. 2000. A synopsis of the Telonychopodini, a tribe of Pantanalian Chelodesmid millepeds (Polydesmida: Chelodesmidae). Myriapodologica 7(1): 1-13.

HOFFMAN, R.L., GOLOVATCH, S.I., ADIS, J. \& DE MORAIS, J.W. 2002. Diplopoda. In Amazonian Arachnida and Myriapoda (J. Adis, ed.). Pensoft Plubishers, Sofia, p. 505-534.

HOPKIN, S.P. \& READ, H.J. 1992. The Biology of Millipedes. Oxford Science Publications, $233 \mathrm{p}$.

JUNK, W.J., NUNES-DA-CUNHA, C., WANTZEN, K.M., PETERMANN, P., STRÜSSMANN, C., MARQUES, M.I. \& ADIS, J. 2006. Biodiversity and its conservation in the Pantanal of Mato Grosso, Brazil. Aquat. Sci. 68:278-309. 10.1007/s00027-006-0851-4

JUNK, W.J., PIEDADE, M.T.F., LOURIVAL, R., WITTMANN, F., KANDUS, P., LACERDA, L.D., BOZELLI, R.L., ESTEVES, F.A., NUNES-DACUNHA, C., MALTCHIK, L., SCHÖNGART, J., SCHAEFFERNOVELLI, Y., AGOSTINHO, A.A., NOBREGA R.L.B. \& CAMARGO, E. 2015. Classificação e delineamento das áreas úmidas brasileiras e de seus macrohabitats. In Definição e classificação das áreas úmidas (AUs) brasileiras, base científica para uma nova política de proteção e manejo sustentável (C. Nunes-da-Cunha, M.T.F. Piedade \& W.J. Junk, eds.). INCT/ INAU - EdUFMT, Cuiabá, p. 13-76.

KIME, R.D. \& GOLOVATCH, S.I. 2000. Trends in the ecological strategies and evolution of millipedes (Diplopoda). Biol. J. Linn. Soc. Lond. 69:3: 333-349. https://doi.org/10.1111/j.1095-8312.2000.tb01209.x

KNYSAK, I. \& MARTINS, R. 1999. Myriapoda. In Invertebrados Terrestres. Biodiversidade do Estado de São Paulo. Síntese do conhecimento ao final do século XX (C.A. Joly, C.E.M. Bicudo, Org.). FAPESP, São Paulo, p. 65-72.

MACHADO, M.P., PIRES, L.R., SILVA, L.T.P., RIGUETE, J.R. \& SILVA, A.G. 2012. Análise de um gradiente fitofisionômico em área de influência de inundação periódica no Pantanal de Poconé, Mato Grosso, Brasil. Natureza On Line 10(2):65-70.

MINELLI, A. \& GOLOVATCH, S.I. 2013. Myriapods. In Encyclopedia of Biodiversity (S.A. Levin ed.). Waltham, Academic Press, p. 421-432.

NORONHA, J.C., BATTIROLA, L.D., CHAGAS-JUNIOR, A., MIRANDA, R., CARPENEDO \& R.S., RODRIGUES, D.J. 2015. Predation of bat (Molossus molossus: Molossidae) by the centipede Scolopendra viridicornis (Scolopendridae) in Southern Amazonia. Acta Amaz. 45:333-336. http:// dx.doi.org/10.1590/1809-4392201404083

NUNES-DA-CUNHA, C., JUNK, W.J. \& LEITÃO, H.F. 2007. Woody vegetation in the Pantanal of Mato Grosso, Brazil, a preliminary typology. Amazoniana19(3):159-184.

NUNES-DA-CUNHA, C. \& JUNK, W.J. 2015. A classificação dos macrohabitats do Pantanal Matogrossense. In Definição e classificação das áreas úmidas (AUs) brasileiras, base científica para uma nova política de proteção e manejo sustentável (C. Nunes-da-Cunha, M.T.F. Piedade \& W.J. Junk, eds.). INCT/INAU - EdUFMT, Cuiabá, p. 77-122.

NUNES-DA-CUNHA, C., REBELLATO, L., DA COSTA, C.P. 2010. Vegetação e flora: experiência pantaneira no sistema de grade. In Biodiversidade no Pantanal de Poconé (I.M. Fernandes, C.A. Signor, \& J.Penha, eds.). Attema, Manaus, p. 37-57.

PEREIRA, L.A., ULIANA, M. \& MINELLI, A. 2007. Geophilomorph centipedes (Chilopoda) from termite mounds in the northern Pantanal wetland of Mato Grosso, Brazil. Stud. Neotrop. Fauna Environ. 42(1):33-48. https://doi. org/10.1080/01650520600915613

PINHEIRO, T.G., MARQUES, M.I. \& BATTIROLA, L.D. 2009. Life cycle of Poratia salvator Sierwald; Golovatch, 2000 (Diplopoda, Polydesmida, Pyrgodesmidae). Zoologia 26:658-662. http://dx.doi.org/10.1590/S198446702009000400010

PINHEIRO, T.G, BATTIROLA, L.D. \& MARQUES, M.I. 2011. Fertility tables of two populations of the parthenogenetic species Poratia salvator (Diplopoda, Polydesmida, Pyrgodesmidae). Braz. J. Biol. 71:501-510. $10.1590 /$ S1519-69842011000300021 
PINHEIRO, T.G. 2013. Ciclo ovogenético e estudo morfológico comparativo do sistema reprodutivo de espécies da ordem Polydesmida (diplopoda). Tese de Doutorado, Universidade Estadual Paulista Julio de Mesquita Filho, Rio Claro. https://repositorio.unesp.br/handle/11449/106579?show=full

REBELLATO, L. \& NUNES-DA-CUNHA, C. 2005. Efeito do "fluxo sazonal mínimo da inundação" sobre a composição e estrutura de um campo inundável no Pantanal de Poconé, MT, Brasil. Acta Bot. Bras. 19:789-799. 10.1590/S0102-33062005000400015

SANTOS, G.B., MARQUES, M.I., ADIS, J. \& MUSIS, C.R. 2003. Arthropods associated with the canopy of the palm Attalea phalerata Mart. (Arecaceae), in the Pantanal of Poconé, Mato Grosso, Brazil. Rev. Bras. Entomol. 47(2): 211-224. 10.1590/S0085-56262003000200010

SANTOS-SILVA, L., PINHEIRO, T.G., CHAGAS-JR, A., MARQUES, M.I., BATTIROLA, L.D. 2018a. Temporal and spatial variation of Myriapoda (Diplopoda and Chilopoda) assemblages in a Neotropical floodplain. Biota Neotropica 18(2): e20180514. http://dx.doi.org/10.1590/1676-0611BN-2018-0514

SANTOS-SILVA, L., PINHEIRO. T.G., MARQUES, M.I. \& BATTIROLA, L.D 2018b. Phenology of Promestosoma boggianii (Diplopoda, Polydesmida, Paradoxosomatidae) in a Neotropical floodplain. Zoologia 35:e14762. 10.3897/zoologia.35.e14762

SCHELLER, U. 2002. Pauropoda. In Amazonian Arachnida and Myriapoda (J. Adis, ed.). Pensoft Publishers, Sofia, 535-545.
SCHELLER, U. 2007. New records of Pauropoda and Symphyla (Myriapoda) from Brazil with descriptions of new species in Allopauropus, Hanseniella and Ribautiella from the northern Pantanal wetland and from Mato Grosso of Brazil. Amazoniana 19:63-75.

SCHELLER, U. \& ADIS, J. 2002. Symphyla. In Amazonian Arachnida and Myriapoda (J. Adis, ed.). Pensoft Publishers, Sofia, p. 547-554.

SIERWALD, P. \& BOND, J.E. 2007. Current Status of theMyriapod Class Diplopoda (Millipedes): Taxonomic Diversity and Phylogeny. Annu. Rev. Entomol. 52:401-422. doi: 10.1146/annurev.ento.52.111805.090210

SIGNOR, C.A., FERNANDES, I.M. \& PENHA, J. 2010. O Pantanal e o sistema de pesquisa. In Biodiversidade no Pantanal de Poconé (I.M. Fernandes, C.A. Signor \& J. Penha, eds.). Attema Editora, Manaus, p. 13-23.

SILVA, M.P.D., MAURO, R., MOURÃO G. \& COUTINHO, M. 2000. Distribuição e quantificação de classes de vegetação do Pantanal através de levantamento aéreo. Rev. Bras. Bot. 23(2):143-152. 10.1590/S010084042000000200004

TAPIA-CORAL, S.C., LUIZÃO, F.J. \& WANDELLI, E.V. 1999. Macrofauna da liteira em sistemas agroflorestais sobre pastagens abandonadas na Amazônia central. Acta Amaz. 29(3):477-485. http://dx.doi.org/10.1590/180943921999293495.

WANTZEN, K.M., MARCHESE, M.R., MARQUES, M.I. \& BATTIROLA, L.D. 2016. Invertebrates in Neotropical floodplains. In Invertebrates in Freshwater Wetlands (D. Batzer \& D. Boix, eds.). Springer International Publishing, Switzerland, p. 493-524. 